\title{
Literatura polska w oczach Chinki polonistki. Z Li Yinan rozmawiają Elżbieta Winiecka i Joanna Krenz
}

Jest Pani znawczynią historii literatury polskiej, autorką książki poświęconej recepcji literatury polskiej $w$ Chinach. Na poczatek chciatybyśmy zatem zapytać, jak to się stato, że zainteresowała się Pani wtaśnie ta tematyka? Dlaczego na przedmiot swoich badań wybrała Pani Polskę, polski język, kulturę i literaturę?

Studia polonistyczne rozpoczęłam 20 lat temu, w roku 2000, na Pekińskim Uniwersytecie Języków Obcych. Wtedy Polska czy język polski były dla mnie czymś zupełnie nieznanym. Wiedziałam tylko, że Fryderyk Chopin, Maria Skłodowska-Curie i Mikołaj Kopernik to Polacy. Być może ta skromna, ale ważna wiedza również w jakiś sposób przyczyniła się do takiego, a nie innego wyboru. Jako osiemnastoletnia maturzystka, która od dzieciństwa interesowała się literaturą i przeczytała wiele chińskich i europejskich dzieł literackich, marzyłam o studiach na prestiżowej uczelni w Pekinie, $w$ dziedzinie filologii. To marzenie zostało spełnione. Po wielu latach pracy zawodowej doszłam do wniosku, że moje ambicje literackie też w pewnym sensie zostały zaspokojone i nadal mam wiele okazji, by spełniać się w tej dziedzinie. $Z$ tego jestem bardzo zadowolona. 
Jeśli chodzi o recepcję literatury polskiej w Chinach, jako pierwsza zainspirowała mnie moja mistrzyni, wybitna tłumaczka literatury polskiej w Chinach, Pani Profesor Yi Lijun, doktor honoris causa Uniwersytetu Gdańskiego, laureatka nagrody Transatlantyk, odznaczona Krzyżem Kawalerskim Orderu Zasługi Rzeczypospolitej Polskiej oraz Medalem Komisji Edukacji Narodowej i laureatka nagrody za całokształt translatorski w Chinach. W czasie studiów magisterskich, kiedy miałam napisać pracę semestralną o literaturze polskiej, przypadała akurat 200. rocznica śmierci Adama Mickiewicza. Pani Profesor Yi Lijun zaproponowała, abym opracowała temat „Adam Mickiewicz w oczach Chińczyków”. Pokazała mi, kto, kiedy i co napisał oraz gdzie opublikowano te teksty. Zaczęłam śledzić badania nad Mickiewiczem w Chinach, a mój artykuł ukazał się niebawem w chińskim numerze „Studiów Języków i Kultur Europejskich”. Kilka lat później, gdy już pracowałam jako wykładowca w Katedrze Języka Polskiego, zostałam zaproszona na międzynarodową konferencję naukową Literatura polska w świecie: obecności zorganizowaną przez Uniwersytet Śląski, na której wygłosiłam referat pt. Polska wspótczesna literatura kobieca w oczach Chinki-polonistki. Przedstawiłam w nim swoje spostrzeżenia dotyczące literatury polskiej. Można rzec, że od tego momentu zaczęłam regularnie zajmować się tą tematyką, a mój mistrz, promotor pracy doktorskiej, prof. Romuald Cudak wprowadził mnie do świata badawczego tej dziedziny.

W swojej książce „Literatura polska w Chinach” pisze Pani o unikalnym charakterze polskiej literatury. Czy mogłaby Pani w kilku zdaniach wyjaśnić, na czym ta unikalność polega? Za co ceni Pani polskich poetów i prozaików?

Polska jako europejski kraj o średniej wielkości pod względem populacji czy powierzchni, w którym urodziło się aż pięcioro noblistów w dziedzinie literatury - sam ten fakt jest już dość wyjątkowy w skali świata, co w pewnym sensie udowadnia unikalność literatury polskiej. Ogólnie rzecz ujmując, interpretacje twórczości polskich pisarzy w Chinach zawierają refleksje o wartości ideolo- 
gicznej, wartości artystycznej, w tym o stylu językowym, myśli filozoficznej, sposobie narracji itp. Te elementy przeplatają się w odbiorze poszczególnych pisarzy. Adam Mickiewicz, Henryk Sienkiewicz są rzecznikami narodu, apelują o walkę o wolność, niepodległość i szanowanie historii oraz tradycji Rzeczypospolitej; poezja Czesława Miłosza wyraża humanistyczną troskę i dociera do istoty ludzkiego istnienia; w poezji Wisławy Szymborskiej uwidacznia się bogata wyobraźnia i gę̨boki światopogląd; a wspominając o najświeższej laureatce Nagrody Nobla Oldze Tokarczuk, wzrusza mnie jej „czuła narracja”, która z naturalną delikatnością i łagodnością kobiety, a jednocześnie bystrym okiem stara się zatopić w sercu wszystkich rzeczy, wtopić się w kosmiczną rzeczywistość, a potem wypowiadać w imieniu wszystkich istot i całego świata.

Chiny to ogromny kraj. Czy, Pani zdaniem, Chińczycy wiedza cokolwiek o Polsce? Z czym i z kim im się ona najczęściej kojarzy?

Kiedy mówi się o Polsce w Chinach, kojarzy się ją zwykle jako ojczyznę Fryderyka Chopina, Marii Skłodowskiej-Curie i Mikołaja Kopernika. Dzisiaj, w dobie globalizacji, dzięki dynamicznie się rozwijającym kontaktom między Chinami a Polską coraz więcej znanych Polaków weszło w horyzont świadomości kulturalnej Chińczyków, np. Andrzej Wajda, Roman Polański, Robert Lewandowski, Krystian Lupa itd. Za sprawą udanej współpracy gospodarczej polski bursztyn cieszy się ogromną popularnością, a polskie produkty żywnościowe, takie jak: mleko, ser, kiełbasa pojawiają się na stołach Chińczyków. Należy jednak podkreślić, że Polska w oczach Chińczyków przypomina kraj, w którym rodacy Adama Mickiewicza przeżywali tragedie historyczne i udowadniali swój patriotyzm, odwagę i silną wolę w dążeniu do wolności i niepodległości. Polska była przez 123 lat pod zaborami, a potem jeszcze pod okupacją nazistów, a Chiny od połowy XIX wieku znalazły się pod wplywem kolonializmu europejskich mocarstw. Podobne doświadczenie historyczne spowodowało zainteresowanie Chińczyków historią Polski i jej literaturą uznaną przez nas (Chińczyków) za broń w walce o wolność i niepodległość. 
Wielu badaczy uważa, że nie da się zrozumieć najważniejszych dziet polskiej literatury poza kontekstem romantycznego paradygmatu, rozumianego nie tylko jako epoka historyczna, ale także pewien model myślenia, wrażliwości i system wartości. Czy łatwo jest uczyć chińskich studentów historii polskiej literatury? Jaka rolę odgrywa kontekst historyczny wich lekturach polskich dziet?

Absolutnie się zgadzam, że bez wiedzy o historii Polski nikt nie nauczy się historii literatury polskiej. W Chinach, zwłaszcza na polonistyce Pekińskiego Uniwersytetu Języków Obcych, zajęcia historia Polski i historia literatury polskiej są zawsze prowadzone paralelnie, ponadto prowadzimy szkicowe wykłady o zarysie historii Polski w języku chińskim na samym początku studiów. Według chińskich dydaktyków języka i kultury polskiej literaturę należy rozumieć w kontekście historycznym. Trudno wyobrazić sobie, aby chiński student niemający wiedzy o wojnie północnej, zrozumiał Potop Henryka Sienkiewicza. Poza tym przywiązujemy szczególną wagę do tego, aby studenci poznawali polską historię na tle całej Europy czy nawet całego świata. Inaczej mówiąc, aby uczyć historii literatury polskiej, trzeba pomóc studentom zdobyć wiedzę ogólną.

Chciałabym jednak zaznaczyć, że polska klasyka nie jest całkiem niezrozumiała dla przeciętnych, nieznających polskiej historii czytelników. Wydaje mi się, że między kulturą chińską a polską istnieje takie uniwersalium pomagające chińskim odbiorcom w rozumieniu tekstu. Ów wspólny zestaw doświadczeń obejmuje szacunek do przodków i pozostawionego przez nich dziedzictwa, traumę po wrogich najazdach, dążenie do wolności narodu i niepodległości państwa suwerennego, pochwałę bohaterstwa i poświęcenia swoich rodaków. Wysokie oceny dla Pana Tadeusza, Trylogii czy Dziadów na portalu Douban (chińskiej wersji Lubimyczytać.pl) są tego dowodem.

Kto czyta polska literaturę $w$ Chinach, oprócz studentów filologii polskiej? Gdyby miała Pani swoich rodaków zachęcić do sięgnięcia po dzieła Polaków, których by im Pani polecita? No i jakich argumentów użyłaby Pani, aby przekonać ich, że warto poznać arcydzieła polskiej literatury? 
Polska literatura w Chinach nie jest taką rzadkością, jak błędnie sądzi wielu europejskich czytelników. Oczywiście, z różnych powodów nie jest ona wśród chińskich miłośników literatury zagranicznej taka znana, jak literatura francuska, brytyjska czy rosyjska, ale dzięki skutecznej działalności promocyjnej, a przede wszystkim urokowi samych utworów, literatura polska przykuwa uwagę coraz większych rzesz Chińczyków. Na przykład na wydanie Zbioru wierszy Zbigniewa Herberta w przekładzie bardzo wielu czytelników czekało z ogromnym zainteresowaniem. Znaczna część chińskich studentów polonistyki zdecydowała się na te studia właśnie ze względu na fascynację polską literaturą.

Nie ulega wątpliwości, literatura polska jest głęboko zakorzeniona w historii i tradycji, nawet w najnowocześniejszych utworach widać takie ślady. Natomiast należy zauważyć, że w dzisiejszych czasach najbardziej zachwycające elementy w polskiej literaturze dla chińskich czytelników to nowoczesność w sposobie narracji i troskliwość o egzystencję ludzi oraz wszechświata.

Zapewne nie istnieje coś takiego jak uniwersalny kod literackiej komunikacji. Niemniej popularność kanonicznych dziet literatury światowej opiera się na odwołaniu ich autorów do wspólnoty wyobraźni, wrażliwości, uniwersalnych wartości. Tak się dzieje przynajmniej wtedy, gdy myślimy o świecie kultury zachodniej... Czy te uniwersalia sa zrozumiałe dla odbiorcy z odmiennego kręgu kulturowego, który reprezentuja Chiny? Czy dostrzega Pani podobne mechanizmy siegania do uniwersaliów u polskich pisarzy? Jeśli tak, to u których?

Uniwersalia $\mathrm{w}$ danym kręgu literackim na pewno istnieją. Starożytna literatura chińska charakteryzowała się przede wszystkim rytmiczną narracją i skupiała się na polityce, zachwycie nad krajobrazem i naturą oraz celebrowaniu przyjaźni czy miłości. Natomiast rzadko widać w niej kody religijne, które często znajdujemy w piśmiennictwie starożytnej Polski. Religijność charakterystyczna dla polskiej kultury jest właśnie tą stosunkowo trudno zrozumiałą wartością dla chińskich czytelników. Mimo to, moim zdaniem, podobne doświadczenie historyczne spowodowało empatię Chińczyków względem polskich bohaterów literackich. Chińscy 
odbiorcy rozumieją traumę historyczną Polaków, doceniają ich waleczność, odwagę, bohaterstwo i patriotyzm pokazane w dziełach Henryka Sienkiewicza i epopei Adama Mickiewicza. Żyjąc w dobie globalizacji, Chińczycy również rozumieją obawę o losy świata Olgi Tokarczuk czy świadomość ekologiczną Wisławy Szymborskiej. Jednym słowem, dzięki udanym przekładom literackim dziś już nie ma zasadniczej bariery kulturowej między chińskimi czytelnikami a polskimi twórcami.

Czy wśród obecnych studentów polonistyki w Pekinie widzi Pani zainteresowanie literatura polska, czy te $\dot{z}$ motywacje do nauki języka polskiego sa zupetnie inne? Czy jest szansa na kolejne pokolenie wybitnych ttumaczy literackich?

Odpowiedź na ostatnie pytanie brzmi zdecydowanie „tak”! Według niepełnych danych statystycznych studenci polonistyki na Pekińskim Uniwersytecie Języków Obcych w czasie studiów już przełożyli i wydali kilkanaście książek dla dzieci. Doktorantka Zhao Weiting przełożyła Pieska przydrożnego Czesława Miłosza (2016), magistrantki Zhao Zhen i Cui Xiaojing przełożyły Szafę Olgi Tokarczuk (2020). Absolwenci ośrodków języka i kultury polskiej PUjo i innych uczelni aktywnie angażują się w tłumaczenie literatury polskiej. Oni są najświeższą siłą promocji literatury polskiej w Chinach.

Pekińska polonistyka jako najstarsza instytucja nauczania języka polskiego w Chinach powstała w roku 1954 w celu kształcenia przede wszystkim tłumaczy praktycznych dla współpracy chińsko-polskiej. Faktycznie, pierwotną motywacją do nauki języka polskiego przez długi czas było w Chinach tłumaczenie ustne, dyplomacja czy studia polskie. Jednakże każde pokolenie wykładowców przywiązywało wielką wagę do zachęcania studentów do poznawania literatury, co wynikało z przekonania, że literatura, jako jeden z najważniejszych obszarów studiów polonistycznych, stanowi fundament wiedzy o Polsce. Bez wiedzy o literaturze trudno poznać historię i społeczeństwo Polski, a także posługiwać się językiem polskim na wysokim poziomie. Katedra Języka Polskiego na PUJo oferuje zajęcia z historii literatury, tłumaczenia 
literackiego oraz interpretacji tekstów literackich na wszystkich trzech stopniach kształcenia akademickiego. Organizuje się tutaj konferencje naukowe poświęcone literaturze, wieczory poetyckie, warsztaty i konkursy tłumaczenia literackiego. Dzięki tym działaniom zainteresowanie literaturą polską wśród studentów staje się coraz większe.

Naszą rozmowę chcialybyśmy zakończyć pytaniem o Pani prywatne upodobania lekturowe: którego z polskich pisarzy i poetów lubi Pani najbardziej? Dlaczego?

To jest bardzo trudne pytanie, gdyż literatura polska jest taka obfita i różnorodna, a jej dorobek tak ogromny, że naprawdę niełatwo mi zdecydować, który utwór jest najbliższy mojemu sercu. Henryk Sienkiewicz swoim starannym literackim pędzlem odmalował majestatyczny krajobraz polskiej historii, Zbigniew Herbert zwięzłym językiem przekazywał głębokie myśli o losach Polaków, a Eliza Orzeszkowa jako jedna z pierwszych feministek tworzyła polską literaturę kobiecą ... Kiedy tłumaczyłam Pocztę literacka... Wisławy Szymborskiej, nie mogłam przestać zachwycać się jej mądrością ukrytą pod warstwą delikatnej ironii. Jeśli musiałabym wybrać jednego naj..., to bez wątpienia Olga Tokarczuk, która jest jednocześnie jedną z ulubionych postaci polskiego świata literackiego wśród moich rodaków.

Moje osobiste zainteresowanie noblistką zaczęło się od powieści Dom dzienny, dom nocny i Prawiek i inne czasy w thumaczeniu Pani Profesor Yi Lijun. Dzięki lekturom tych przekładów poznałam nazwisko Olgi Tokarczuk i jej twórczość. Miałam okazję spotkać autorkę, kiedy w 2008 roku odwiedziła polonistykę PUJo, gdzie pracuję. Olga Tokarczuk wygłosiła wówczas wykład dla studentów i prowadziła bardzo ciepłą i przyjazną rozmowę z kadrą, m.in. tłumaczami jej książek Profesor Yi Lijun i jej mężem. Zapamiętałam ją dobrze jako sympatyczną, spokojną kobietę, a jej słowa miały w sobie jakąś magiczną energię, która skłaniała mnie do refleksji. Od tamtego momentu zostałam miłośniczką Olgi Tokarczuk. W późniejszych latach jako studentka Pani Profesor Yi Lijun miałam szczęście być świadkiem ich wzajemnej interakcji na Świa- 
towym Kongresie Tłumaczy i podczas uroczystego wręczenia nagrody Transatlantyk Profesor Yi Lijun. Czułam empatię pisarki, która wyraża się także w jej utworach i przemowie noblowskiej.

Dla mnie (i moich rodaków) Olga Tokarczuk i jej twórczość są wyjątkowe. Pisarka jest w Chinach porównywana do Gabriela Garcíi Márqueza ze względu na magiczny realizm obecny w jej utworach oraz do chińskiego noblisty Mo Yana słynącego z niebywałej sprawności w prowadzeniu narracji. Głębiej analizując jej twórczość, przekonujemy się, że trudno ją zaklasyfikować do jakiegoś rodzaju bądź tradycji literatury polskiej. Pisarka od dawna świadomie trzymała pewien dystans do rodzimej tradycji literackiej, ściślej mówiąc, od dawna deklaruje swoje niezadowolenie względem niej. Jest szczególnie świadoma tego, że tradycja to nie tylko przewaga czy bogactwo, ale także ograniczenie w pisaniu. Oczywiście, w jej utworach nadal wyraźnie widać wpływ innych pisarzy, np. jej umiejętność przedstawiania szczegółów przypomina Henryka Sienkiewicza, poetyckość narracji przywodzi na myśl Adama Mickiewicza i Czesława Miłosza, odważna i magiczna wyobraźnia każe przywołać Witolda Gombrowicza, oniryczna atmosfera świata przedstawionego - Brunona Schulza, a dowcip i lekkość - Wisławę Szymborską. W jej utworach można dostrzec ślady wielu poprzednich polskich pisarzy, ale trudno uznać ją za ich imitatorkę, cały czas pozostaje ona sobą i tylko sobą. Realizm, romantyzm, modernizm, magia i tajemnica, baśnie i mitologia tworzą w jej dziełach cudowną mieszankę.

Mówi się, że tłumacz jest pierwszym czytelnikiem danego dzieła. Kiedy tłumaczyłam Opowiadania bizarne, siedziałam właśnie na domowej kwarantannie w Pekinie. Nieraz wzruszałam się czułością pisarki, okazaną w tych opowiadaniach. Poruszyły mnie dyskusja o relacji między człowiekiem a nieznanym światem (Pasażer, Szwy), przemyślenia o konfliktach między ludźmi a zwierzętami, między cywilizacją a naturą (Transfugium, Zielone $d z i e c i)$, refleksja nad tożsamością człowieka (Prawdziwa historia) czy mistycyzm (Przetwory, Serce). Olga Tokarczuk potrafi umiejętnie dekonstruować świat i rekonstruować nadzieję. W jej prozie przejawia się autentyczne zatroskanie o los ludzi i wszechświata, a zarazem wytrwałość w poszukiwaniu przyszłej drogi. Są w niej 
czułość i empatia, a przy tym ogromne pokłady nadziei. Wydaje mi się, że Olga Tokarczuk daje nam nadzieję, która jest najcenniejszą istotą jej twórczości, a także całej literatury polskiej.

Joanna Krenz, Elżbieta Winiecka

\section{Tender Narration: The New Face of Polish Literature in the Eyes of the Chinese}

The article presents the dynamics, characteristics and the shifting paradigms of the reception of Polish literature in China from 2012 to 2020. The author analyses the reasons for the popularity of the most often translated and read Polish authors on the Chinese publishing market, with particular interest in Czesław Miłosz, Olga Tokarczuk and Andrzej Sapkowski. She also presents the translators - both experienced and often recognised and awarded doyens of Polish studies in China, and those from the intermediate and youngest generations to whom the oldest ones passed the knowledge, skills, passion and the sense of common mission of building cross-cultural dialogue through literature.

Keywords: reception of Polish literature; Polish literature in China; translation of Polish literature; Chinese translators.

Li Yinan - assistant professor, ur. 7 października 1981 roku, kierownik Katedry Języka Polskiego na Pekińskim Uniwersytecie Języków Obcych. W latach 2012-2015 III sekretarz w Ambasadzie Chińskiej Republiki Ludowej w Polsce. Uhonorowana Odznaką „Zasłużony dla Kultury Polskiej” nadaną przez Ministra Kultury i Dziedzictwa Narodowego RP. Zajmuje się wymianą kulturalną między Chinami a Polską od wielu lat. Badaczka i tłumaczka literatury polskiej. Znawczyni studiów międzykulturowych. Jest odpowiedzialna za chiński narodowy grant nauk społecznych na temat wymiany literackiej między Chinami a Polską. Uczestniczy w wielu projektach naukowych na szczeblu państwowym lub ministerialnym. Na jej dorobek naukowy składa się ponad 30 referatów naukowych o literaturze, kulturze i glottodydaktyce $\mathrm{w}$ chińskich i polskich czasopismach i periodykach. Jest autorką monografii pt. Literatura polska $w$ Chinach nominowanej do Nagrody im. Jana Kochanowskiego w roku 2019. Autorka przekładu Poczty literackiej czyli jak zostać (lub nie zostać) pisarzem Wisławy Szymborskiej, Opowiadań bizarnych Olgi Tokarczuk i podręcznika Język polski dla poczatkujacych. 
Joanna Krenz - adiunkt w Instytucie Orientalistyki UAM, obecnie realizuje staż postdoktorski na Uniwersytecie Zuryskim. Tłumaczka i badaczka literatury chińskiej. Jej zainteresowania naukowe koncentrują się wokół literatury współczesnej, w tym zwłaszcza najnowszej poezji chińskiej, w perspektywie komparatystycznej w ujęciu interkulturowym i interdyscyplinarnym, a także wokół związków między literaturą a naukami ścisłymi oraz technologią.

Elżbieta Winiecka - doktor habilitowana, profesor UAM, dyrektorka Instytutu Filologii Polskiej UAM, pracowniczka Zakładu Literatury i Kultury Nowoczesnej w IFP UAM. Redaktorka „Poznańskich Studiów Polonistycznych. Serii Literackiej”. Zainteresowania badawcze: literatura i kultura xx i XXI wieku, literatura elektroniczna. Ostatnio opublikowała Poszerzanie pola literatury. Studia o literackości w internecie (2020). Adres e-mail: elzbieta. winiecka@amu.edu.pl. 